Bull. Chem. Soc. Ethiop. 2013, 27(1), 15-23.

Printed in Ethiopia

ISSN 1011-3924

DOI: http://dx.doi.org/10.4314/bcse.v27i1.2

(c) 2013 Chemical Society of Ethiopia

\title{
REMOVAL OF NICKEL(II) AND PALLADIUM(II) FROM SURFACE WATERS
}

\author{
Fatemeh Sabermahani ${ }^{1,2^{*}}$, Mahboubeh Saeidi ${ }^{3}$ and Vajihe Sharifzade ${ }^{2}$ \\ ${ }^{1}$ Department of Chemistry, Payame Noor University, P.O. Box 19395-4697, Tehran, Iran \\ ${ }^{2}$ Department of Chemistry, Payame Noor University of Kerman, Kerman, Iran \\ ${ }^{3}$ Department of Chemistry, Vali-e-asr University of Rafsanjan, Kerman, Iran
}

(Received February 1, 2012; revised July 13, 2012)

\begin{abstract}
A new sorbent was prepared using alumina and 5-Br-PADAP, and its adsorption ability for the removal of $\mathrm{Ni}$ (II) and $\mathrm{Pd}$ (II) from different waters was investigated. The procedure is based on retention of the analytes on the alumina load with 5-Br-PADAP at $\mathrm{pH} \sim 6$. The separation/preconcentration conditions for the quantitative recoveries were investigated. The limit of detections (LOD) based on three times the standard deviations of the blank, were 0.187 and $0.253 \mathrm{ng} \mathrm{mL}^{-1}$ for $\mathrm{Ni}$ (II) and $\mathrm{Pd}(\mathrm{II})$, respectively. Obtained sorption capacities for $1 \mathrm{~g}$ sorbent were $6.0 \mathrm{mg} \mathrm{Ni}$ (II) and $11.0 \mathrm{mg} \mathrm{Pd}(\mathrm{II})$. The linearity was maintained in the concentration range of 0.625 to $6.0 \mathrm{ng} \mathrm{mL}^{-1}$ for $\mathrm{Ni}$ (II) and 0.416 to $7.0 \mathrm{ng} \mathrm{mL}^{-1}$ for $\mathrm{Pd}$ (II) in the original solution. Eight replicate determinations of a mixture containing $2.0 \mu \mathrm{g} \mathrm{mL}^{-1}$ each of the elements in the final solution gave relative standard deviation of \pm 0.82 and $\pm 1.12 \%$ for $\mathrm{Ni}$ (II) and $\mathrm{Pd}$ (II), respectively. The proposed method was successfully applied to the determination trace amounts of $\mathrm{Ni}(\mathrm{II})$ and $\mathrm{Pd}(\mathrm{II})$ in the surface water samples.
\end{abstract}

KEYWORDS: Alumina, Surface water, Nickel(II), Palladium(II), Preconcentration

\section{INTRODUCTION}

Nickel is widely used in electroplating, in the manufacture of Ni-Cd batteries, in rods for arc welding, in pigments for paint, in ceramics, in surgical and dental prostheses, in magnetic tapes and computer components and in nickel catalysts. Nickel enters waters from dissolution of rocks and soils, from biological cycles, from atmospheric fallout, especially from industrial processes and waste disposal [1]. Nickel was thought be essential to plants and some domestic animals [2], but not considered to be a metal of biological importance until 1975, when Zerner discovered that urease was a nickel enzyme $[3,4]$. Nickel is an essential constituent of plant urease. Urease-rich legumes such as jack beans and soybeans generally contain high nickel concentrations [1]. Compared with other transition metals, nickel is a moderately toxic element. However, it is known that inhalation of nickel and its compounds can lead to serious problems, including cancer of the respiratory system [5]. Moreover, nickel can cause a skin disorder known as nickel-eczema [6]. Eczema develops in places where nickel-containing metal is touching the skin.

Palladium is used as a matrix modifier for the determination of several metals by electrothermal atomic absorption spectrometry [7, 8]. Owing to its corrosion resistance nature and alloying ability, it is an important element in metallurgy. Its alloys are used in dental and medicinal devices and in jewellery manufactures. Palladium has an extensive use in electrical industry as grids for electronic tubes and electrodes for high quality spark plugs. It is also used as catalytic converter in motor vehicles. Therefore, this metal may accumulate along motorways and on soil surface and street dust [9].

Nickel and palladium can enter waters from industrial processes and waste disposal, beside; they enter environmental samples such as surface water, from dissolution of soils and street dust. Therefore, it is necessary and important to develop sensitive methods for determining nickel and palladium in environmental samples.

*Corresponding author. E-mail: fatemehsaber2003@yahoo.com 
Owing to the co-existence of various heavy metal ions in industrial effluents or other water resources, selective separation of toxic metal ions attracts much attention in both industries and researches. Selective adsorption of an ion on suitable solid sorbent possessing selectivity is inherently attractive to remove metal ions from dilute aqueous solution. For this purpose, many enrichment methods have been proposed and used to separate and preconcentrate trace elements, according to nature of the samples, the concentration of the analytes and the measurement techniques [10]. Different methods have been applied to extract $\mathrm{Ni}$ (II) and $\mathrm{Pd}(\mathrm{II})$ ions in water samples including liquid-liquid extraction [11], cloud point extraction [12-16], coprecipitation [17], ion exchange [18], liquid phase micro extraction [19-21], voltammetry [22, 23 ] and solid phase extraction [9, 24-32]. The liquid-liquid extraction and separation methods are usually time-consuming and labor extensive, and require relatively large volumes of high purity solvents. Of additional concern is disposal of the organic solvent used, which creates a severe environmental problem. Solid phase extraction (SPE) has known as a powerful tool for separation and enrichment of various inorganic and organic analytes. SPE has several advantages over other techniques, including stability and reusability of the solid phase, high preconcentration factors, ease of separation and enrichment under dynamic conditions, no need for organic solvents, which may be toxic and minimal costs due to low consumption of reagents [33].

Aluminum oxide is one of the most widely used adsorbents, as it does not swell and has good mechanical strength, small solubility and stability in a broad $\mathrm{pH}$ range [34]. Immobilization of organic compounds on the surface of the solid support is usually aimed at modifying the surface with certain target functional groups for a higher selectivity of the extraction. The selectivity of the modified solid phases toward certain metal ions is attributed to several well-known factors, such as the size of the organic compound used to modify the sorbent, the activity of the loaded surface groups and the type of the interaction of functional group [35].

2-(5-Bromo-2-pyridylazo)-5-diethylaminophenol (5-Br-PADAP), one of commercially available and cheap pyridylazo reagents has been used in determination of trace metals, including cadmium [36, 37] and zinc [38].

There is no report on complexation of PADAP with Pd(II) ions or immobilization on the surface of alumina. The preliminary experiments showed that the bare alumina can adsorb a lot of metal ions, but, adsorption was not selective and the recoveries were incomplete. By immobilization of the ligand PADAP on the alumina, only, $\mathrm{Ni}(\mathrm{II})$ and $\mathrm{Pd}(\mathrm{II})$ can be adsorbed in the specified $\mathrm{pH}$. On the other hand, the coating of alumina with the ligand increases the adsorption capacity for $\mathrm{Ni}(\mathrm{II})$ and $\mathrm{Pd}(\mathrm{II})$. Also, since, the conditions of the proposed method, was proper for simultaneous extraction and preconcentration of $\mathrm{Pd}(\mathrm{II})$ and $\mathrm{Ni}(\mathrm{II})$, only. For example the both elements were adsorbed at $\mathrm{pH}=6$ and desorbed with $3.0 \mathrm{~mL}$ of $1 \mathrm{M}$ thiourea and then $2.0 \mathrm{~mL} 3 \mathrm{M}$ of $\mathrm{HCl}$, simultaneously. Therefore, these two elements were selected and examined for the proposed method.

This work is devoted to the preparation and evaluation of the sorption properties of alumina modified with PADAP to preconcentration trace amounts of $\mathrm{Ni}$ (II) and Pd(II) from surface water samples. The analytical conditions for the selective extraction of analytes elements were investigated.

\section{EXPERIMENTAL}

\section{Materials}

The stock solutions of $\mathrm{Ni}(\mathrm{II})$ and $\mathrm{Pd}(\mathrm{II})\left(1000.0 \mathrm{mg} \mathrm{L}^{-1}\right.$ ), were prepared by dissolving $0.5196 \mathrm{~g}$ of nickel nitrate (99.99\%, Merck, Darmstad, Germany), in distilled water and $0.1660 \mathrm{~g} \mathrm{PdCl}_{2}$ (99.999\%, Aldrich, Milwaukee, USA) in $2 \mathrm{M} \mathrm{HCl}$ (37.0\%, Merck, Darmstad, Germany), and 
diluting to $100.0 \mathrm{~mL}$ with distilled water, separately. The standard working solutions were diluted daily prior to use. A $0.01 \%(\mathrm{~m} / \mathrm{v})$ solution of the 5-Br-PADAP (99.999\%, Aldrich, Milwaukee, WI, USA) was prepared by dissolving $0.01 \mathrm{~g}$ of this reagent in ethanol $(96.0 \%$, Merck, Darmstad, Germany), and diluting to $100.0 \mathrm{~mL}$ with ethanol. Buffer solution was prepared from 0.2 M potassium dihydrogen phosphate (99.5\%, Aldrich, Milwaukee, WI, USA) and $0.2 \mathrm{M}$ dipotassium hydrogen phosphate $(99.5 \%$, Aldrich, Milwaukee, WI, USA) for pH 6. A solution of thiourea $1.0 \mathrm{M}$ was prepared by dissolving $7.680 \mathrm{~g}$ of thiourea $(99.0-101 \%$, Merck, Darmstad, Germany), in distilled water and diluting to $100.0 \mathrm{~mL}$ with distilled water. $\mathrm{Al}_{2} \mathrm{O}_{3}(0.063-0.2 \mathrm{~mm}$ or 70-230 mesh ASTM) (Merck, Darmstad, Germany) was used as sorbent.

\section{Apparatus}

An atomic absorption spectrometer model Sens AA (Dandenong, Victoria, Australia) equipped with deuterium lamp background corrector was used for determination of $\mathrm{Ni}$ and $\mathrm{Pd}$ in airacetylene flame. The instrumental settings of the spectrometer were as follows: wavelength, 232.0 and $244.8 \mathrm{~nm}$; slit width of 0.2 and $0.2 \mathrm{~nm}$; lamp current, 4 and $5 \mathrm{~mA}$; acetylene flow 1.5 $\mathrm{L} \mathrm{min}^{-1}$ and air flow 3.5 $\mathrm{L} \mathrm{min}^{-1}$ for $\mathrm{Ni}$ and Pd, respectively. A mechanical shaker KS 130 basic (Deutschland, Germany) having speed control and timer was used for preparation of the sorbent. Funnels-tipped glass tube $(5 \times 100 \mathrm{~mm})$ equipped with stopcock were used as column for the preconcentration purposes. The bed height the adsorbent in the column was approximately 10 mm. A 691 Metrohm pH meter (Herisau, Switzerland) was employed for $\mathrm{pH}$ measurements.

\section{Adsorbent preparation}

Amount of $3.0 \mathrm{~g}$ alumina was added to $50 \mathrm{~mL}$ of the solution containing $0.01 \%$ PADAP in a stoppered Pyrex glass flask, and the mixture was shaken on mechanical shaker (Model KS 130 basic, Deutschland, Germany) having speed control and timer at room temperature for $2 \mathrm{~h}$. The reagent coated alumina was filtered through a cellulose membrane filter (Millipore) of $0.45 \mu \mathrm{m}$ pore size, washed with distilled water tree times and dried at room temperature for $24 \mathrm{~h}$.

\section{General procedure}

Funnel-tipped glass tube (ten columns, $10 \mathrm{~cm}$ long and $0.5 \mathrm{~cm}$ in diameter) equipped to stopcock was used as the column for preconcentration purposes. A small amount of glass wool was placed in the end of the columns to prevent loss of the sorbent during sample loading. Then, the columns were packed with $100 \mathrm{mg}$ of the alumina coated with PADAP and conditioned with a buffer solution at $\mathrm{pH} \sim 6$. The bed height the adsorbent in the column was approximately $10 \mathrm{~mm}$. An aliquot of the sample solution containing Ni(II) (0.25-30.00 $\mu \mathrm{g}$ ) and $\mathrm{Pd}(\mathrm{II})(0.25-40.00 \mu \mathrm{g})$ was taken in a $50 \mathrm{~mL}$ beaker and to it was added $2 \mathrm{~mL}$ phosphate buffer solution with $\mathrm{pH} 6$. The total volume of the solution was made up to about $30 \mathrm{~mL}$ with distilled water. It was then passed through the column containing $100 \mathrm{mg}$ of the sorbent with flow rate of $2 \mathrm{~mL} \mathrm{~min}^{-1}$. The flow rate of solution was controlled by using a stopcock in end of the column. The retained metal ions were eluted from the solid phase with $3.0 \mathrm{~mL}$ of $1.0 \mathrm{M} \mathrm{HCl}$ and then 2.0 $\mathrm{mL}$ of thiourea $1.0 \mathrm{M}$. This solution was aspirated into an air-acetylene flame for the determination of $\mathrm{Ni}$ (II) and $\mathrm{Pd}(\mathrm{II})$ by FAAS. Calibration curves for the determination of $\mathrm{Ni}(\mathrm{II})$ and $(\mathrm{Pd}(\mathrm{II})$ were prepared according to the proposed procedure under the optimum conditions. 
Analysis of real samples

The method was applied to determine NI(II) and Pd(II) from water different samples including river and spring water from Baft and Ravar in Kerman, and a sea water from Khazar Sea in Iran. The water samples were filtered through a cellulose membrane filter (Millipore) of $0.45 \mu \mathrm{m}$ pore size. A volume $50.0 \mathrm{~mL}$ of water samples was transferred to a beaker, and $\mathrm{pH}$ was adjusted to 6 by addition of the buffer solution. Then the proposed procedure was applied to these samples. The levels of analyte ions in the samples were determined by flame atomic absorption spectrometry.

In order to evaluate the accuracy of the procedure, recovery experiments were also carried out with spiked water samples because of certified reference material for the $\mathrm{Ni}(\mathrm{II})$ and $\mathrm{Pd}(\mathrm{II})$ was not available. The recovery percentages of $\mathrm{Ni}$ (II) and $\mathrm{Pd}$ (II) ions were evaluated and the results showed that the real samples matrixes did not affect the recovery of these ions.

\section{RESULTS AND DISCUSSION}

Preliminary experiments showed that the bare alumina can adsorb a lot of metal ions, but, adsorption was not selective and the recoveries were incomplete (for example Ni: $72 \%, \mathrm{Cu}$ : 84\%, Co: 78\%, Fe: 90\%, Mn: 80\%, Pd: 92\%, Ag: 30\%, Cd: 87\%). By immobilization of the ligand PADAP on the alumina, only, $\mathrm{Ni}$ (II) and $\mathrm{Pd}(\mathrm{II})$ can be adsorbed in the specified $\mathrm{pH}$. On the other hand, the coating of alumina with the ligand increases adsorption capacity for $\mathrm{Ni}$ (II) and Pd(II). In order to achieve the best performance, the separation/preconcentration procedure was optimized for various analytical parameters, such as $\mathrm{pH}$ of the sample, the flow rate of eluent and sample solution, amount of the adsorbent, volume and type of the eluent solution, volume of the buffer and volume of the sample solution. Interference effects of various ions were also investigated.

\section{Effect of the sample $\mathrm{pH}$}

Since the $\mathrm{pH}$ of the aqueous solutions is an important analytical factor in solid phase extraction studies of metal ions [39], the influence of $\mathrm{pH}$ on the recovery of analyte ions was examined in the $\mathrm{pH}$ range of $2-10$ by using diluted solutions of $\mathrm{HNO}_{3}$ and $\mathrm{NaOH}$ or proper buffers. As can be seen from Figure 1, Ni(II) ions were quantitatively recovered at $\mathrm{pH}$ range of 5-10, while $\mathrm{Pd}(\mathrm{II})$ ions were recovered at $\mathrm{pH}$ range of 6-9. In order to avoid hydrolyzing and determine these elements, simultaneously, $\mathrm{pH} 6$ was selected for further study and was kept constant at 6 using potassium dihydrogen phosphate buffer solution.

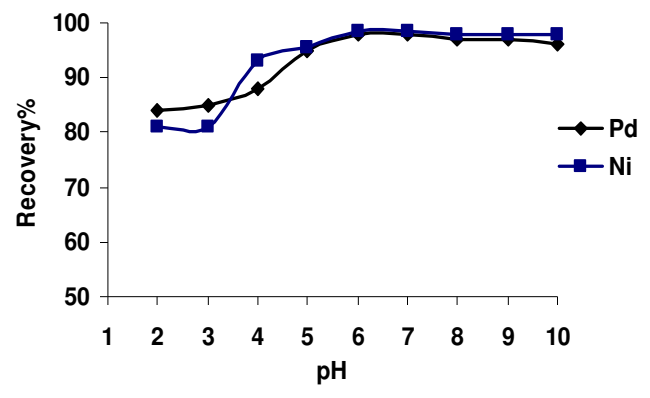

Figure 1. Effect of $\mathrm{pH}$ on the recovery of $\mathrm{Ni}(\mathrm{II})$ and $\mathrm{Pd}(\mathrm{II})$ after preconcentration with the proposed method. Conditions: $\mathrm{Ni}(\mathrm{II}), 10.0 \mu \mathrm{g}$; $\mathrm{Pd}(\mathrm{II}), 10.0 \mu \mathrm{g} ; \mathrm{pH} \sim 6$; buffer, $3.0 \mathrm{~mL}$; flow rate, $2.0 \mathrm{~mL} \mathrm{~min}^{-1}$; sorbent, $100.0 \mathrm{mg}$. Instrumental conditions as in Table 1.

Bull. Chem. Soc. Ethiop. 2013, 27(1) 


\section{Effect of type and concentration of eluent}

Desorption of the retained Ni(II) and Pd(II) from the column was tested using various eluting agents. Since the complex of the Pd(II) with PADAP is stable, many of the reagents could not elute $\mathrm{Pd}(\mathrm{II})$ from the column, completely. As can be seen from Table 1, maximum recoveries have been obtained by using $3.0 \mathrm{~mL}$ of $1 \mathrm{M} \mathrm{HCl}$ and then $2.0 \mathrm{~mL}$ of $1 \mathrm{M}$ thiourea (final volume $5.0 \mathrm{~mL}$ ). Therefore, in all the experiments $3.0 \mathrm{~mL}$ of $1 \mathrm{M} \mathrm{HCl}$ and then $2.0 \mathrm{~mL}$ of $1 \mathrm{M}$ thiourea were used for simultaneous desorption of $\mathrm{Ni}(\mathrm{II})$ and $\mathrm{Pd}(\mathrm{II})$.

Table 1. Effect of elution solutions on the recoveries of Ni(II) and Pd(II).

\begin{tabular}{|l|c|c|}
\hline \multirow{2}{*}{ Solution } & \multicolumn{2}{|c|}{ Recovery\% $^{\text {a }}$} \\
\cline { 2 - 3 } & $\mathrm{Ni}(\mathrm{II})$ & $\mathrm{Pd}(\mathrm{II})$ \\
\hline $5.0 \mathrm{~mL}$ of $1.0 \mathrm{M} \mathrm{HCl}$ & 74.6 & 82.0 \\
\hline $5.0 \mathrm{~mL}$ of $1.0 \mathrm{M} \mathrm{HNO}_{3}$ & 81.0 & 80.0 \\
\hline $5.0 \mathrm{~mL}$ of $1.0 \mathrm{M}$ thiourea & 83.0 & 51.0 \\
\hline $5.0 \mathrm{~mL}$ of $1.0 \mathrm{M} \mathrm{Na}_{2} \mathrm{SO}_{3}$ & 65.0 & 25.0 \\
\hline $5.0 \mathrm{~mL}$ of $1.0 \mathrm{M} \mathrm{H}_{2} \mathrm{SO}_{4}$ & 60.0 & 11.0 \\
\hline $5.0 \mathrm{~mL} \mathrm{mixture} \mathrm{of} 2.0 \mathrm{M} \mathrm{HCL}$ and $1.0 \mathrm{M}$ thiourea & 93.0 & 97.5 \\
\hline $3.0 \mathrm{~mL} 1.0 \mathrm{M}$ thiourea and then $2.0 \mathrm{~mL} 3.0 \mathrm{M} \mathrm{HCl}$ & 98.0 & 98.5 \\
\hline
\end{tabular}

${ }^{a}$ Average of three determinations, \pm standard deviation. Conditions: Ni(II), $10.0 \mu \mathrm{g} ; \mathrm{Pd}(\mathrm{II}), 10.0 \mu \mathrm{g} ; \mathrm{pH} \sim 6$; buffer, $3.0 \mathrm{~mL}$; flow rate, $2.0 \mathrm{~mL} \mathrm{~min}^{-1}$; sorbent, $100.0 \mathrm{mg}$. Instrumental settings: wavelength, 232.0 and 244.8 $\mathrm{nm}$; slit width 0.2 and $0.2 \mathrm{~nm}$; lamp current, 4 and $5 \mathrm{~mA}$; acetylene flow $1.5 \mathrm{~L} \mathrm{~min}^{-1}$ and air flow $3.5 \mathrm{~L} \mathrm{~min}^{-1}$ for nickel and palladium, respectively.

\section{Effect of flow rate of sample and eluent solution}

The retention of an element on a sorbent also depends on the flow rate of the sample solution [40]. Thus, the effect of flow rate of the sample and elution solution on the retention and recovery of ions was investigated under optimum conditions $(\mathrm{pH}=6$; elution solution $3.0 \mathrm{~mL}$ of $1 \mathrm{M} \mathrm{HCl}$ and then $2.0 \mathrm{~mL}$ of $1 \mathrm{M}$ thiourea). The solution containing $\mathrm{Ni}(\mathrm{II})$ and $\mathrm{Pd}(\mathrm{II})$ was passed through the column with the flow rates adjusted in the range $0.5-3 \mathrm{~mL} \mathrm{~min}^{-1}$. It was observed that, a flow rate of $3 \mathrm{~mL} \mathrm{~min}{ }^{-1}$ was adequate for $\mathrm{Ni}$ (II) and $2 \mathrm{~mL} \mathrm{~min}^{-1}$ for $\mathrm{Pd}$ (II). At flow rates greater than $2 \mathrm{~mL} \mathrm{~min}^{-1}$ there was a decrease in the recovery of $\mathrm{Pd}(\mathrm{II})$, probably due to insufficient contact of the metal ions and the sorbent to reach equilibrium [40]. Therefore, a flow rate of $2 \mathrm{~mL} \mathrm{m^{-1 }}$ was applied for simultaneous adsorption of $\mathrm{Ni}$ (II) and $\mathrm{Pd}$ (II) in subsequent experiments. Also, for desorption of metal ions, flow rate was varied between 0.5-3 $\mathrm{mL} \mathrm{min}^{-1}$ and a flow rate of $2 \mathrm{~mL} \mathrm{m^{-1 }}$ was found adequate for simultaneous desorption of $\mathrm{Ni}(\mathrm{II})$ and $\mathrm{Pd}(\mathrm{II})$.

\section{Effect of amount of the sorbent}

The amount of sorbent is another important parameter that affects the recovery [41]. A quantitative retention is not obtained when the amount of sorbent is less [41]. On the other hand, an excess amount of resin prevents the elution of the retained chelates by a small amount of eluent quantitatively [41]. For this purpose, different amounts of the sorbent (10-200 mg) were examined. The results showed that quantitative recoveries $(>95 \%)$ of the metal ions were obtained when the sorbent quantity was greater than $50 \mathrm{mg}$. $100 \mathrm{mg}$ of the sorbent was selected for further experiments. The column filled with $100 \mathrm{mg}$ adsorbent can be regenerated over 100 cycles of adsorption-desorption cycles without any significant change in the retention of $\mathrm{Ni}$ (II) and $\mathrm{Pd}(\mathrm{II})$. It can be recovered with about $10 \mathrm{~mL}$ of the elution solution and then water, subsequently. 


\section{Breakthrough volume}

The measurement of breakthrough volume is important in solid phase extraction because breakthrough volume represents the sample volume that can be preconcentrated without loss of analyte during elution of the sample [39]. The volume of the first aqueous phase, containing a fixed amount of the analytes $(10.0 \mu \mathrm{g} \mathrm{Ni}$ (II) and $10.0 \mu \mathrm{g} \mathrm{Pd}(\mathrm{II}))$, was varied in the range of 50.0-1000.0 $\mathrm{mL}$ under the optimum conditions, keeping other variables constant, and was passed through column for preconcentration. It was found that recovery was quantitative to $400.0 \mathrm{~mL}$ for $\mathrm{Ni}$ (II) and $600.0 \mathrm{~mL}$ for $\mathrm{Pd}(\mathrm{II})$, alone, but for the both elements as simultaneous, at sample volumes $>400 \mathrm{~mL}$ the recoveries decreased gradually with increasing volume of sample solution. Since the elution solution volume was $5.0 \mathrm{~mL}$; preconcentration factors were obtained 80 for $\mathrm{Ni}(\mathrm{II})$ and 120 for Pd(II).

\section{Sorption capacity of the sorbent}

To determine the amount of analyte retained on the column, for a specific mass of sorbent, several solutions differing in concentrations were made and introduced into the column. Ten milliliters of solutions containing $\mathrm{Ni}$ (II) and $\mathrm{Pd}(\mathrm{II})$ at concentrations in the range of 20.0-150.0 $\mathrm{mg} \mathrm{L} \mathrm{L}^{-1}$ were passed through the columns containing exactly $100.0 \mathrm{mg}$ of the sorbent under optimum conditions. The eluting solutions were collected and the presence of the analyte in each was tested by FAAS. When $\mathrm{Ni}$ (II) and Pd(II) were detected in the eluate, the test was stopped and the sorption capacity calculated. The sorption capacities were found to be $6.0 \mathrm{mg}$ $\mathrm{Ni}^{2+}$ and $11.0 \mathrm{mg} \mathrm{Pd}^{2+}$ for $1.0 \mathrm{~g}$ sorbent.

\section{Effect of foreign ions}

Various salts and metal ions were added to a solution containing $\mathrm{Ni}(\mathrm{II})$ and $\mathrm{Pd}(\mathrm{II})$ and the general procedure was applied. The tolerance limit was set as the concentration of the ion required to cause $\pm 3 \%$ error $[42,43]$. The results obtained are given in Table 2 . Among the metal ions and salts studied, most did not interfere. Thus, this method is selective and can be used for the determination of $\mathrm{Ni}(\mathrm{II})$ and $\mathrm{Pd}(\mathrm{II})$ in the water samples.

Table 2. Effect of different salts and metal ions on the extraction and preconcentration of $\mathrm{Ni}(\mathrm{II})$ and $\mathrm{Pd}(\mathrm{II})$.

\begin{tabular}{|l|c|c|}
\hline \multirow{2}{*}{ Salt or ion } & \multicolumn{2}{|c|}{ Tolerance limit (mg) } \\
\cline { 2 - 3 } & $\mathrm{Ni}(\mathrm{II})$ & $\mathrm{Pd}(\mathrm{II})$ \\
\hline $\mathrm{Na}_{2} \mathrm{SO}_{4}$ & 400 & 500 \\
\hline $\mathrm{KI}$ & 400 & 700 \\
\hline $\mathrm{Na}_{2} \mathrm{~S}_{2} \mathrm{O}_{3}$ & 200 & 400 \\
\hline $\mathrm{KBrO}_{3}$ & 400 & 500 \\
\hline $\mathrm{Na}_{2} \mathrm{CO}_{3}$ & 300 & 150 \\
\hline $\mathrm{NaCl}, \mathrm{KCl}, \mathrm{NaF}$ & 500 & 500 \\
\hline $\mathrm{NaHCO}_{3}$ & 400 & 400 \\
\hline $\mathrm{CH}_{3} \mathrm{COONa}_{3} 3 \mathrm{H}_{2} \mathrm{O}$ & 300 & 400 \\
\hline $\mathrm{Ca}^{2+}$ & 500 & 500 \\
\hline $\mathrm{Pb}^{2+}$ & 2.0 & 2.0 \\
\hline $\mathrm{Co}^{2+}$ & 5.0 & 5.0 \\
\hline $\mathrm{Cu}^{2+}$ & 3.0 & 5.0 \\
\hline $\mathrm{Cd}^{2+}, \mathrm{Cr}^{3+}$ & 3.0 & 4.0 \\
\hline $\mathrm{Ag}^{+}$ & 2.5 & 2.0 \\
\hline
\end{tabular}

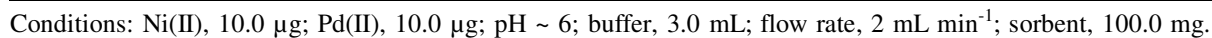
Instrumental conditions are the same as in Table 1. 


\section{Analytical performance}

The analytical performance of the proposed procedure can be shown for the results of FAAS measurements. The linearity was maintained in the concentration range of $0.05-6.0 \mu \mathrm{g} \mathrm{mL}^{-1}$ in the final solution or $0.625-6.0 \times 10^{3} \mathrm{ng} \mathrm{mL}^{-1}$ in the original solution for $\mathrm{Ni}$ (II) and $0.05-7.0 \mu \mathrm{g}$ $\mathrm{mL}^{-1}$ in the final solution or $0.416-7.0 \times 10^{3} \mathrm{ng} \mathrm{mL}^{-1}$ in the original solution for $\mathrm{Pd}(\mathrm{II})$. The equations of the lines are $\mathrm{A}=0.0636 \mathrm{C}+8.16 \times 10^{-3}$ for $\mathrm{Ni}(\mathrm{II})$ and $\mathrm{A}=0.0415 \mathrm{C}+5.6 \times 10^{-4}$ for $\mathrm{Pd}(\mathrm{II})$ in the final solution, respectively where $\mathrm{A}$ is the absorbance and $\mathrm{C}$ is concentration of the metal ions $\left(\mu \mathrm{g} \mathrm{mL}^{-1}\right)$. The regression coefficients for the lines are 0.9981 and 0.9967 for $\mathrm{Ni}(\mathrm{II})$ and $\mathrm{Pd}(\mathrm{II})$, respectively.

The preconcentration factors for $\mathrm{Ni}(\mathrm{II})$ and $\mathrm{Pd}(\mathrm{II})$ according to $5.0 \mathrm{~mL}$ eluent and the workable maximum sample volumes $(400$ and $600 \mathrm{~mL}$ ) were calculated as 80 and 120 , respectively. Eight replicate determinations of $10.0 \mu \mathrm{g}$ nickel and $10.0 \mu \mathrm{g}$ palladium in the 5.0 $\mathrm{mL}$ final solution gave a relative standard deviation of $\pm 0.82 \%$ for $\mathrm{Ni}(\mathrm{II})$ and $\pm 1.12 \%$ for $\operatorname{Pd}(\mathrm{II})$. The limit of detections (LOD) for the analytes ions based on $3 \sigma_{\mathrm{bl}} / \mathrm{m}(\mathrm{n}=8)$ were 0.187 $\mathrm{ng} \mathrm{mL} \mathrm{m}^{-1}$ for $\mathrm{Ni}(\mathrm{II})$ and $0.253 \mathrm{ng} \mathrm{mL}^{-1}$ for $\mathrm{Pd}(\mathrm{II})$ and limit of quantification (LOQ) were 0.625 and $0.416 \mathrm{ng} \mathrm{mL}^{-1}$ for $\mathrm{Ni}(\mathrm{II})$ and $\mathrm{Pd}(\mathrm{II})$, respectively, in the original solution.

\section{Application to real samples}

To assess the capability of the method for real samples with different matrices containing varying amounts of diverse ions, the method was applied to determine nickel and palladium indifferent water samples. The results are given in Table 3. According to the results, the concentrations of $\mathrm{Ni}(\mathrm{II})$ and $\mathrm{Pd}(\mathrm{II})$ in analyzed water samples were below the LOD of the method. The suitability of the proposed method for the analysis of natural water samples was checked by spiking the samples with 5.0 and $10.0 \mathrm{~mL}$ of $2.0 \mu \mathrm{g} \mathrm{mL}^{-1}$ of the analyte ions. Good recoveries were obtained for all analyzed samples (Table 3).

Table 3. Determination of $\mathrm{Ni}(\mathrm{II})$ and $\mathrm{Pd}(\mathrm{II})$ in the water samples after preconcentration with the proposed method.

\begin{tabular}{|c|c|c|c|c|c|c|}
\hline \multirow[t]{2}{*}{ Sample } & \multicolumn{2}{|c|}{ Added $\left(\mathrm{ng} \mathrm{mL}^{-1}\right)$} & \multicolumn{2}{|c|}{ Found $\left(\mathrm{ng} \mathrm{mL}^{-1}\right)^{\mathrm{a}}$} & \multicolumn{2}{|c|}{ Recovery (\%) } \\
\hline & $\mathrm{Ni}(\mathrm{II})$ & $\mathrm{Pd}(\mathrm{II})$ & $\mathrm{Ni}(\mathrm{II})$ & Pd(II) & $\mathrm{Ni}(\mathrm{II})$ & $\operatorname{Pd}(\mathrm{II})$ \\
\hline \multirow[t]{3}{*}{ River water ${ }^{b}$} & 0.0 & 0.0 & ND & ND & ---- & +--- \\
\hline & 5.0 & 5.0 & $5.10 \pm 0.04$ & $5.05 \pm 0.10$ & 102.0 & 101.0 \\
\hline & 10.0 & 10.0 & $10.07 \pm 0.08$ & $10.03 \pm 0.14$ & 100.7 & 100.3 \\
\hline \multirow{3}{*}{$\begin{array}{l}\text { Spring } \\
\text { water }^{\mathrm{c}}\end{array}$} & 0.0 & 0.0 & ND & ND & --- & --- \\
\hline & 5.0 & 5.0 & $4.94 \pm 0.06$ & $5.11 \pm 0.10$ & 98.8 & 102.2 \\
\hline & 10.0 & 10.0 & $10.01 \pm 0.07$ & $9.71 \pm 0.19$ & 100.1 & 98.9 \\
\hline \multirow[t]{3}{*}{ River water $^{\mathrm{c}}$} & 0.0 & 0.0 & ND & ND & ---- & ---- \\
\hline & 5.0 & 5.0 & $5.04 \pm 0.05$ & $5.00 \pm 0.11$ & 100.8 & 100.0 \\
\hline & 10.0 & 10.0 & $10.15 \pm 0.07$ & $10.07 \pm 0.09$ & 101.5 & 100.7 \\
\hline \multirow[t]{3}{*}{ Sea water ${ }^{\mathrm{d}}$} & 0.0 & 0.0 & ND & ND & ---- & ---- \\
\hline & 5.0 & 5.0 & $4.88 \pm 0.22$ & $5.10 \pm 0.10$ & 97.6 & 102.0 \\
\hline & 10.0 & 10.0 & $10.28 \pm 0.31$ & $9.70 \pm 0.20$ & 102.8 & 97.0 \\
\hline
\end{tabular}

ND: not detected; sample volume: $50.0 \mathrm{~mL}$; ${ }^{\mathrm{a}}$ average of three determinations, \pm S.D.; ${ }^{\mathrm{b} B a f t,}$ Kerman, Iran; ${ }^{\mathrm{c}}$ Ravar, Kerman, Iran; ${ }^{\mathrm{d}}$ Khazar Sea, Iran. Conditions: $\mathrm{pH} \sim 6$; buffer, $3.0 \mathrm{~mL}$; flow rate, $2 \mathrm{~mL} \mathrm{~min}^{-1}$; sorbent, $100.0 \mathrm{mg}$. 
Comparison with other methods

Comparative data from some papers on solid phase extraction of trace $\mathrm{Ni}(\mathrm{II})$ and $\mathrm{Pd}(\mathrm{II})$ are summarized in Table 4. The analytical performance is not significantly different from those achieved by other methods described in the literature. The detection limits of investigated elements are superior to those of some preconcentration/separation methods [9, 29, 44-50]. The sorption capacities are also better or comparable with the other methods. The matrix effects with the method were reasonably tolerable. Good recoveries were obtained for the environmental samples, demonstrating that the method can be successfully applied to these samples.

Table 4. Comparative data from some recent studies on preconcentration of analyte ions.

\begin{tabular}{|l|c|c|c|c|c|c|}
\hline Sorbent/reagent & Analyte & $\mathrm{PF}^{\mathrm{a}}$ & $\begin{array}{c}\text { Sorption capacity } \\
\left(\mathrm{mg} \mathrm{g}^{-1}\right)\end{array}$ & $\begin{array}{c}\text { LOD } \\
\left(\mathrm{ng} \mathrm{mL}^{-1}\right)\end{array}$ & RSD\% & Ref. \\
\hline Silica gel/dimethyl golyoxime & $\mathrm{Pd}(\mathrm{II})$ & 75.0 & 4.06 & 1.20 & 1.7 & {$[9]$} \\
\hline Ambersorb 572/EDTA & $\mathrm{Ni}(\mathrm{II})$ & 50.0 & $0.21^{\mathrm{b}}$ & 1.42 & 2.0 & {$[29]$} \\
\hline Silica gel/polyethylene glycol & $\mathrm{Ni}(\mathrm{II})$ & 83.3 & 8.30 & 0.71 & 3.1 & {$[44]$} \\
\hline Octadecyl silica/thioridazin & $\mathrm{Pd}(\mathrm{II})$ & 100 & 0.44 & 12.0 & 1.2 & {$[45]$} \\
\hline XAD-2000/diethyldithio carbamate & $\mathrm{Ni}(\mathrm{II})$ & 100 & 3.80 & 0.25 & --- & {$[46]$} \\
\hline Chromosorb 108 & $\mathrm{Ni}(\mathrm{II})$ & 80.0 & 4.90 & 0.44 & 1.4 & {$[47]$} \\
\hline Nanometer-size $\mathrm{TiO}_{2}$ & $\mathrm{Pd}(\mathrm{II})$ & 50.0 & 11.8 & 12.0 & 7.4 & {$[48]$} \\
\hline Coprecipitation & $\mathrm{Ni}(\mathrm{II})$ & 30.0 & ----- & 3.60 & 2.7 & {$[49]$} \\
\hline XAD-7/KI & $\mathrm{Pd}(\mathrm{II})$ & 37.3 & ----- & 24.9 & $1.6-8.9$ & {$[50]$} \\
\hline 5-Br-PADAP/alumina & $\mathrm{Ni}(\mathrm{II})$ & 80.0 & 6.0 & 0.19 & 0.8 & Present \\
& $\mathrm{Pd}(\mathrm{II})$ & 120 & 11.0 & 0.25 & 1.12 & method \\
\hline
\end{tabular}

${ }^{\mathrm{a}} \mathrm{PF}$ : preconcentration factor; ${ }^{\mathrm{b}} \mathrm{mmol} \mathrm{g}{ }^{-1}$.

\section{CONCLUSIONS}

The new sorbent 5-Br-PADAP/alumina could be successfully applied for simultaneous separation and preconcentration of nickel(II) and palladium(II) in water samples. This solid phase extractant has the following advantages: preparation of the sorbent is simple, rapid and low cost. The modified alumina can be regenerated over 100 cycles of adsorption-desorption without any significant change in the retention of $\mathrm{Ni}(\mathrm{II})$ and $\mathrm{Pd}(\mathrm{II})$. The accuracy of the results was verified by analyzing the spike water samples. The good precision and high tolerance to interferences from matrix ions are other advantages. Thus, it may be concluded that the method in an effective approach in separation and preconcentration of nickel and palladium in water samples.

\section{REFERENCES}

1. Merian, E.; Anke, M.; Ihnat, M.; Stoeppler, M. Elements and Their Compounds in the Environment, Vol. 2, 2nd ed., Wiley/VCH: Weinheim; 2004.

2. Wang, K. Nickel Trace Elements in Life Science, Chinese Measurement Press: Peking, China; 1991.

3. Zerner, B. Bioorg. Chem. 1991, 19, 116.

4. Thauer, R.K. Science 2001, 293, 1264.

5. Templeton, D. Biological Monitoring of Chemical Exposure in the Workplace, Word Health Organization: Geneva; 1990.

6. Kristiansen, J.; Kristiansen, J.M.; Henriksen, T.; Nielsen, N.H. Anal. Chim. Acta 2000, 403, 265.

7. Tsalev, D.L.; Slaveykova, V.I. J. Anal. At. Spectrom. 1992, 7, 147. 
8. Acar, O.; Turker, A.R.; Kilic, Z. Fresenius J. Anal. Chem. 1998, 360, 645.

9. Tokaloglu, S.; Oymak, T.; Kartal, S. Anal. Chim. Acta 2004, 511, 255.

10. Mizuike, A. Enrichment Techniques for Inorganic Trace Analysis, Springer-Verlag: Berlin; 1983.

11. Pan, L.; Qin, Y.; Hu, B.; Jiang, Z. Chem. Res. Chin. Univ. 2007, 23, 399.

12. Sahin, C.A.; Efecinar, M.; Satiroglu, N. J. Hazard. Mater. 2010, 176, 672.

13. Siva, E.L.; Roldan, P.S.; Gine, M.F. J. Hazard. Mater. 2009, 171, 1133.

14. Lemos, V.A.; Franca, R.S.; Moreira, B.O. Sep. Purif. Technol. 2007, 54, 349.

15. Shokoufi, N.; Shemirani, F.; Shokoufi, M. Spectrochim. Acta 2009, 74, 761.

16. Tavallali, H.;Yazdandoust, S.; Yazdandoust, M. Clean - Soil, Air, Water 2010, 38, 242.

17. Soylak, M.; Kars, A.; Narin, I. J. Hazard. Mater. 2008, 159, 435.

18. Moawed, E.A. Anal. Chim. Acta 2006, 580, 263.

19. Liang, P.; Zhao, E.; Li, F. Talanta 2009, 77, 1854.

20. Abulhassani, J.; Manzoori, J.; Amjadi, M. J. Hazard. Mater. 2010, 176, 481.

21. Shemirani, N.F.; Assadi, Y. Anal. Chim. Acta 2007, 597, 349.

22. Moneeb, M.S. Talanta 2006, 70, 1035.

23. Kim, S.; Cha, K.W. Talanta 2002, 57, 675.

24. Hu, Q.; Huang, X.Z.; Chen, J. J. Chromatogr. A 2005, 1094, 77.

25. Yin, J.; Jiang, Z.; Chang, G.; Hu, B. Anal. Chim. Acta 2005, 540, 333.

26. Yin, P.; Xu, Q.; Qu, R.; Zhao, G. J. Hazard. Mater. 2009, 169, 228.

27. Zylkiewicz, B.G.; Kozlowska, M. Anal. Chim. Acta 2005, 539, 61.

28. Chwastowska, J.; Sterlinska, W.E.; Pszonicki, L. Talanta 2004, 64, 224.

29. Baytak, S.; Turker, A.R. J. Hazard. Mater. 2006, 129, 130.

30. Chaisuwan, T.; Komalwanich, T.; Luangsukrerk, S.; Wongkasemjit, S. Desalination 2010, 256, 108.

31. Baytak, S.; Kocyigit, A.; Turker, A.R. Clean-Soil, Air, Water 2007, 35, 607.

32. Soylak, M.; Unsal, Y.E.; Aydin, A.; Kizil, N. Clean - Soil, Air, Water 2010, 38, 91.

33. Azimi, G.; Zolgharnein, J.; Sangi, M.R.; Ebrahimi, S. Anal. Sci. 2009, $25,711$.

34. Chibowski, S.; Opalamazur, E.; Patkowski, J. Mater. Chem. Phys. 2005, 93, 262.

35. Tewari, P.K.; Singh, A.K. Analyst 2000, 125, 2350.

36. Pyrzynska, K.; Kilian, K. Water Res. 2007, 41, 2839.

37. Nazari, S. Microchem. J. 2008, 90, 107.

38. Escudero, L.A.; Martinez, L.D.; Salonia, J.A.; Gasquez, J.A. Microchem. J. 2010, 95, 164.

39. Shamspur, T.; Mostafavi, A. J. Hazard. Mater. 2009, 168, 1548.

40. Sabermahani, F.; Taher, M.A.; Bahrami, H. Fozooni, S. J. Hazard. Mater. 2011, 185, 945.

41. Kenduzler, E.; Rehber Turker, A. Anal. Sci. 2002, 18, 917.

42. Rostampour, L.; Taher, M.A. Talanta 2008, 75, 1279.

43. Afzali, D.; Taher, M.A.; Mostafavi, A.; Mohammadi Mobarakeh, S.Z. Talanta 2005, 65, 476.

44. Pourreza, N.; Zolgharnein, J.; Kiasat, A.R. Talanta 2010, 81, 773.

45. Farhadi, K.; Teimouri, G. Talanta 2005, 65, 925.

46. Bulut, V.N.; Gundoglu, A.; Duran, C.; Senturk, H.B.; Elci, L.; Tufekci, M. J. Hazard. Mater. 2007, 146, 155.

47. Tuzen, M.; Soylak, M.; Elci, L. Anal. Chim. Acta 2005, 548, 101.

48. Qing, Y.; Hang, Y.; Wanjaul, R.; Jiang, Z. Anal. Sci. 2003, 19, 1417.

49. Aydin, F.A.; Soylak, M. Talanta 2007, 73, 134.

50. Elci, L.; Soylak, M.; Buyuksekerci, E.B. Anal. Sci. 2003, 19, 1621. 